\title{
ARTWORKS OF RUSSIAN STONE CARVERS IN THE DIPLOMATIC SERVICE*
}

\author{
Rev. of: Mavrodina, N. M. (2019). Proizvedeniya russkogo kamnereznogo \\ iskusstva za predelami Rossii. Spravochnik [Works of Russian Stone-Carving \\ Art in Collections outside Russia. Reference Book]. St Petersburg, Izdatel'stvo \\ Gosudarstvennogo Ermitazha. 160 p.;
}

Budrina, L. A. (2020). Malakhitovaya diplomatiya [Malachite Diplomacy]. Moscow, Yekaterinburg, Kabinetnyi uchenyi. 208 p.

Sergey Vinokurov

Yekaterinburg Museum of Fine Arts, Ural Federal University, Yekaterinburg, Russia

This review examines recently published works by Russian scholars in the field of artistic stone carving, namely, the reference book by N. M. Mavrodina, Works of Russian Stone-Carving Art in Collections outside Russia (2019), and the monograph by L. A. Budrina, Malachite Diplomacy (2020). Both works study objects created by Russian stone carving artists through the 18th - early twentieth century and which left the country as a result of various diplomatic occasions. The authors have adopted different research approaches. N. M. Mavrodina, preparing a catalogue of works exported from Russia, focuses mainly on the activities of Imperial stone-carving factories. The monograph by L. A. Budrina, on the other hand, focuses on the identification and study of carvings and their history; it also offers insights into the role of stone-carved objects in the formation of the image of the Russian state, and describes the main mechanisms that contributed to the formation of a fashion for Russian stone carving abroad. The two reviewed works offer a significant contribution to the historiography of stone carving art, as well as the role of works of art in creating the image of a country or region and their place in the formation of a single European art market.

Keywords: artistic stone carving, Russian Empire, diplomatic relations, museum collections, private collections

Рассматриваются недавно изданные труды российских специалистов в области камнерезного искусства: книга-справочник Н. М. Мавродиной «Про-

* Citation: Vinokurov, S. (2021). Artworks of Russian Stone Carvers in the Diplomatic Service. In Quaestio Rossica. Vol. 9, № 2. P. 761-767. DOI 10.15826/qr.2021.2.608.

Цитирование: Vinokurov S. Artworks of Russian Stone Carvers in the Diplomatic Service // Quaestio Rossica. Vol. 9. 2021. № 2. P. 761-767. DOI 10.15826/qr.2021.2.608. 
изведения русского камнерезного искусства за пределами России» (2019) и монография Л. А. Будриной «Малахитовая дипломатия» (2020). Исследования посвящены изучению предметов, созданных русскими камнерезами в XVIII - начале XX в. и покинувших страну в результате различных дипломатических поводов. Авторы избирают различные исследовательские подходы. Н. М. Мавродина, готовя каталог вывезенных за пределы России произведений, фокусирует свое внимание в основном на деятельности императорских камнерезных предприятий. Монография Л. А. Будриной посвящена выявлению и изучению произведений и связанных с ними событий, а также определению роли предметов отечественного камнерезного искусства в формировании образа государства, обозначению основных механизмов, способствующих формированию моды на русский камень. Рассматриваемые издания вносят существенный вклад в историю изучения камнерезного искусства и роли художественных произведений в создании имиджа страны, места в процессе формирования единого европейского художественного рынка.

Ключевые слова: камнерезное искусство, Российская империя, дипломатические отношения, музейные собрания, частные коллекции

Artistic stone carving and the organization of its domestic production have acted as traditional symbols of prestige for European countries since the Renaissance. It might be useful to recall the workshops and manufacturers opened under the patronage of the Italian House of Medici, Louis XIV of France, or the Spanish King Charles III. Many participants in the political processes of the time were passionate collectors of works made of carved semi-precious stone. In Russia, a distinctive interest in artistic stone carving appeared during the era of Peter the Great, leading to the founding of three Imperial factories: the Peterhoff and Yekaterinburg lapidary factories and the Kolyvan polishing factory. Since the end of the eighteenth century, the capital's private residences began to be filled with the works of Russian stone carvers, and gifts made of carved stone become an important part of international diplomacy. Various exhibition projects of European museums in recent decades have demonstrated a genuine interest in the artistic relations between Russia and other European states [Будрина, 2020, с. 8-9].

One of the first works on the distribution of carved stone artifacts belongs to the pen of the academicians, A. E. Fersman [Ферсман], and V. B. Semenov [Семенов, 1987; Семенов, Тимофеев, 2003а; Семенов, Тимофеев, 2003b]. A catalog of Russian stone works from the collection of the State Hermitage Museum, prepared by N. М. [Мавродина, 2007], presents a systematic account of the stone carving production of Imperial factories through the late eighteenth - early twentieth centuries, incorporating many previously collected materials related to the study or description of these artifacts. Thus, information about Russian carvings found abroad is provided on the basis of archival data and references to existing scholarly discourse. 
For a long time, research was limited to information about the migration of stone carved works and did not consider questions of their global historical context and the possible goals of these trans-border movements. In the last two years, however, a few publications have identified different research approaches to the study of this phenomenon of European culture and summarized the original findings of study into the circumstances surrounding the migration of Russian artistic stone carving abroad.

The first of these works is the reference book Works of Russian Stonecarving Art in Collections outside Russia, published by the State Hermitage Museum (2019). The format of the new edition, which is designated as a "reference book", explains the style of presentation chosen by the authorNatalia Mavrodina - a research fellow at the State Hermitage Museum [Мавродина, 2019].

The book's introductory article presents several interesting examples of the diplomatic gifting of artistic stone carving from the last quarter of the nineteenth century, which coincided with important political events. Time constraints narrow the representativeness of this opening section. The overview is followed by an index; a list of items is arranged in chronological order according to the dates of the objects' migration outside the Russian empire. The accompanying texts describe each stone carving work, the country of its destination, and the person to whom the object was sent. In some cases, a sketch or a blueprint and information about the current location of the object are provided.

Each of the descriptions are accompanied by an indication of relevant sources and literature from which they are drawn, significantly expanded after 2007 thanks to the research of B. Geres, L. A. Budrina, I. O. Sychev, and others. This allowed N. M. Mavrodina to better identify the circumstances of the objects' donations and clarify the information about their current storage location. An example of this is a square malachite bowl, made at the Yekaterinburg lapidary factory in 1838-1840, the location of which was unknown for a long time, and became available thanks to the work of L. A. Budrina, who discovered fragments of this bowl in the Vatican Museums - damaged by collapsing pylons in the Sistine Salon of the Vatican Library [Будрина, 2015].

The information published in the reference book partially duplicates the previously mentioned appendix to the catalog of the State Hermitage Collection [Мавродина, 2007, с. 538-559]. Thus, a number of items with an incomplete history were transferred from the appendix to the reference book almost unchanged (i. e., in fact, they represent an extract from an archival source) [Мавродина, 2019, с. 22-23]. The author's focus on the production of Imperial factories (the only exception being the works created at the Demidov Malachite Factory), also seems to be tied to their reliance on this same appendix, which significantly limits the subject range of the book.

The section of the catalogue centered on a history tracing the migration outside the empire of those carvings with no surviving documentary evidence is of particular interest. Controversially, this "unidentified" 
section includes a number of gifts with previously identified records (for example, the malachite doors from the Demidovs' collection [Мавродина, 2019, с. 132; Будрина, 2013]). It seems fair to exclude this and a number of other items from the list of works with unclear provenance due to new information on their movement that has become available since the book's publication.

The book ends with indexes (sources and names), as well as a list of references, including publications up to 2018. We note a rather modest selection of publications that thematically coincide with the main concept of the reference book.

The second work, which I would like to draw attention to, is the monograph Malachite Diplomacy, published in Yekaterinburg (2020) [Будрина, 2020]. The author of the book is Lyudmila Budrina, Candidate of Art History, Associate Professor of the Ural Federal University [Там же].

The monograph by L. A. Budrina explores the role of Russian stone carving products in the diplomatic relations of the Russian Empire and the circumstances of their distribution around the world through the eighteenth - early twenthieth centuries. The introduction offers a brief essay on the history of artistic stone carving produced by state and private factories in St. Petersburg and Yekaterinburg.

The main objective of the author seems to be an understanding of the use of artistic stone carving in the establishing of the international image of the Russian state [Будрина, 2020, c. 15]. In this context, a special place is occupied by works carved from Ural malachite, which made up the lion's share of Russia's diplomatic gifts to foreign partners from the beginning of the nineteenth century. This preference for the Ural mineral motivated the author's coining of the term «malachite diplomacy», which has since been used in the title of several projects by L. A. Budrina (including a series of public lectures and a documentary film in 2020, which was dedicated to the initial stage of the eventual world fashion for malachite).

The central part of the monograph is an interesting guide to those countries where Russian semi-precious stone works are present today. The information is organized geographically/politically, and chronologically within separate sections. Such an interesting structure turns reading an academic publication into a fascinating journey, allowing one to start reading any of the chapters and follow either the author's narrative or the movements of specific objects through time (for example, the reader might wish to follow the carvings of the Demidov Malachite Factory from Victorian London to Porphyrian Mexico City, when they were presented at the first World Exhibition in 1851) [Будрина, 2020, c. 180-181].

The central part of the book is divided into several chapters, corresponding to individual European countries, and sometimes more distinct political or geographical regions (Benelux, Baltic region). The largest sections are related to the history of the works of Russian stone carvers in France, Germany, and Great Britain. The sections on Spain, Asia, America, and Australia are smaller by comparison. However, this 
heterogeneity is justified both by the statistics related to stone "gifts" of the Russian Empire, and by the uneven intensity of contacts with various countries or regions at the time. The uneven distribution of chapters could also be influenced by the cultural difficulties found in identifying Russian art objects within certain regions of Asia.

The book focuses on those objects the location of which was either previously known or discovered by the author. In the course of the narrative, the author studies the reasons and circumstances for the works' migration outside the country; they also restore in detail the history of objects that have seen repeated changes to their place of storage and, in the process, often lost their Russian provenance. One case related to a writing set carved at the Yekaterinburg Lapidary Factory is particularly illustrative. The set was a gift from the Russian Empress Maria Feodorovna to the French jeweler, Théodule Bourdieu. Over time, this set underwent a change of storage location, but also received new authorship, and, thus, was turned into a diplomatic gift for the second time [Будрина, 2020, с. 29-31].

Budrina pays special attention to the activities of private stone carving enterprises and the mechanisms of migration of their works to foreign collections. In addition to the detailed history of the movement of the works contained within the Demidov collection, created for the London exhibition of 1851 at Demidov's own malachite factory, the author has also identified works made by the capital-located "Gesserich and Woerffel" firm, which started to work with Ural malachite in the 1870s -1880 s [Там же, с. 161-162].

The book also includes information about private stone carving enterprises in Yekaterinburg, among which the production of I. S. Stebakov and V. I. Lipin seems to stand out [Там же, с. 136]. The author considers their activities in two aspects. On the one hand, they acted as worthy competitors of the Yekaterinburg Lapidary Factory and their "neighbors" at World Exhibitions; on the other, they often partnered with their ostensive rivals, sharing in largescale projects. A good example of the latter is the cooperation between the Lapidary Factory and the jewelry workshop of merchant V. I. Lipin during their work on the "Map of France" [Там же, с. 38].

In the conclusion to the monograph, L. A. Budrina rightfully notes that the identification and study of artistic stone carving objects in foreign collections is an ongoing process and needs to be continued and supplemented with new information, as well as new works, which are waiting to be discovered in large and small museums and private collections around the world [Там же, с. 184].

The book ends with a name index (more than two hundred names), as well as an index of the collections in which the Russian artistic stone carving objects are currently represented. The extensive literature section includes descriptions of archival sources from the collections of Russia, France, Germany, the Netherlands, Italy, and the United States. The author provides new information among the book's references about periodicals and publications in Russian, English, French, German, and Italian. The list 
of works by Russian and foreign scholars on the history of artistic stone carving and on the issues surrounding the artistic and diplomatic relations of Russia with other countries gives an exhaustive picture of existing publications on the topic.

Each of the works reviewed here consider similar problems but differ in their objectives. The main objective of the reference book by N. M. Mavrodina is a presentation of the sheer volume of works by Russian stone carvers that were exported outside the borders of the Russian Empire. The publication is of great practical value as a source for further academic research, as well as for the modern art market and the attributions of objects in museums and private collections.

In contrast, the objective of $\mathrm{L}$. A. Budrina's work, covering a much wider range of objects and stone carving factories, is a detailed description of artistic stone carving, produced on a large scale in Russia through the eighteenth - early twentieth centuries. The inclusion of little-studied facts about private stone carving production makes the work especially valuable. In addition, it is important to understand the degree of recognition of Russian artistic stone carving both within the country and abroad. Hence, the format of the narrative, built on a geographical basis and including not only dry facts about diplomatic gifting, but also revealing other interesting ways in which the art works of Russian carvers penetrated foreign art markets. In this way, the significance of artistic stone carving in crosscultural art exchange is properly taken into account.

To sum up, the reviewed works are of undoubted academic value, given they make a significant contribution to the study of the history of artistic stone carving in Russia, as well as expanding our perception of decorative and applied art and its role in promoting the prestige of the state.

\section{Список литературы}

Будрина Л. А. Уральский след в Мексике: перипетии коллекции Демидовых // Веси. 2013. № 8. С. 38-40.

Будрина Л. А. Малахит Святого престола: российские дары понтификам 18401850-х годов // Кучумовские чтения : сб. докл. науч. конф. «Атрибуция, история и судьба предметов из императорских коллекций». СПб. : ГМЗ «Павловск», 2015. C. 33-44.

Будрина Л. А. Малахитовая дипломатия. М. ; Екатеринбург : Кабинетный ученый, 2020. $208 \mathrm{c}$.

Мавродина Н. М. Искусство русских камнерезов XVIII-XIX веков : каталог коллекции. СПб. : Изд-во Гос. Эрмитажа, 2007. 560 с.

Мавродина Н. М. Произведения русского камнерезного искусства за пределами России : справочник. СПб. : Изд-во Гос. Эрмитажа, 2019. 160 с.

Семенов В. Б. Малахит = Malachite : [в 2 т.]. Свердловск : Сред.-Урал. книж. издво, 1987. Т. 2. 140 с. (Сер.: Камни Урала.)

Семенов В. Б., Тимофеев Н. И. Екатеринбургская гранильная фабрика: 1861-1917. Екатеринбург : ИГЕММО «Lithica», 2003a. 496 c.

Семенов В. Б., Тимофеев Н. И. Екатеринбургская камнерезная и антиковая фабрика: 1805-1861. Екатеринбург : ИГЕММО «Lithica», 2003b. 752 c.

Ферсман А. Е. Очерки по истории камня : в 2 т. М. : Изд-во Акад. наук СССР, 1961. T. $2.372 \mathrm{c}$. 


\section{References}

Budrina, L. A. (2013). Ural'skii sled v Meksike: peripetii kollektsii Demidovykh [The Ural Trace in Mexico. Adventures of the Demidovs' Collection]. In Vesi. No. 8, pp. 38-40.

Budrina, L. A. (2015). Malakhit Svyatogo prestola: rossiiskie dary pontifikam 18401850-kh godov [The Malachite of the Holy See: Russian Gifts to Pontiffs in the 1840s-1850s]. In Kuchumovskie chteniya. Sbornik dokladov nauchnoi konferentsii "Atributsiya, istoriya $i$ sud'ba predmetov iz imperatorskikh kollektsii”. St Petersburg, Gosudarstvennyi muzeizapovednik "Pavlovsk", pp. 33-44.

Budrina, L. A. (2020). Malakhitovaya diplomatiya [Malachite Diplomacy]. Moscow, Yekaterinburg, Kabinetnyi uchenyi. 208 p.

Fersman, A. E. (1961). Ocherki po istorii kamnya $v 2 t$. [Essays on History of Gemstones. 2 Vols.]. Moscow, Izdatel'stvo Akademii nauk SSSR. Vol. 2. 372 p.

Mavrodina, N. M. (2007). Iskusstvo russkikh kamnerezov XVIII-XIX vekov. Katalog kollektsii [The Art of Russian Stone Carvers between the $18^{\text {th }}$ and $19^{\text {th }}$ centuries. Catalogue of the Collection]. St Petersburg, Izdatel'stvo Gosudarstvennogo Ermitazha. 560 p.

Mavrodina, N. M. (2019). Proizvedeniya russkogo kamnereznogo iskusstva za predelami Rossii. Spravochnik [Works of Russian Stone-Carving Art in Collections outside Russia. Reference Book]. St Petersburg, Izdatel'stvo Gosudarstvennogo Ermitazha. 160 p.

Semenov, V. B. (1987). Malakhit $v 2$ t. [Malachite. 2 Vols.]. Sverdlovsk, SredneUral'skoe knizhnoe izdatel'stvo. Vol. 2. 140 p.

Semenov, V. B., Timofeev, N. I. (2003a). Ekaterinburgskaya granil'naya fabrika: 1861-1917 [The Yekaterinburg Lapidary Factory in 1861-1917]. Yekaterinburg, Istorikogemmologicheskoe obshchestvo "Lithica". $496 \mathrm{p}$.

Semenov, V. B., Timofeev, N. I. (2003b). Ekaterinburgskaya kamnereznaya i antikovaya fabrika: 1805-1861 [The Yekaterinburg Lapidary Factory in 1805-1861]. Yekaterinburg, Istoriko-gemmologicheskoe obshchestvo "Lithica". 752 p.

The article was submitted on 25.12.2020 